International Journal of Agriculture and Environmental Research

ISSN: 2455-6939

Volume: 06, Issue: 06 "November-December 2020"

\title{
ALLELOPATHY OF TIRIRICA (Cyperus rotundus L.) ON ARABIC COFFEE SEEDLINGS
}

João Marcos Ferreira de Moraes Caproni ${ }^{1}$, Kleso Silva Franco Júnior ${ }^{2}$, Giselle Prado Brigante ${ }^{3}$

\author{
${ }^{1}$ Agronomy student, Department of Agronomy, Centro Superior de Ensino e Pesquisa (CESEP), \\ Av. Dr. Ataíde Pereira de Souza, 730 - Centro, Machado - MG, 37750-000. \\ ${ }^{2,3}$ Agronomic engineer, Department of Agronomy, Centro Superior de Ensino e Pesquisa (CESEP), \\ Av. Dr. Ataíde Pereira de Souza, 730 - Centro, Machado - MG, 37750-000.
}

DOI: https://doi.org/10.51193/IJAER.2020.6604

\begin{abstract}
Allelopathy is considered as the capacity that the plant has to produce substances that influence, favorably or not, the power over other plants. Thus, the present study aims to evaluate the effect of different concentrations of tiririca extract (Cyperus rotundus L.) on the development of Arabica coffee seedlings. The study was carried out in the municipality of Carvalhópolis / MG. Six treatments were performed, control (without the use of extract), extract at $1 \%, 2 \%, 3 \%, 4 \%$ and 5\%, with 4 repetitions, totaling 24 experimental plots, in a randomized block design (DBC). It was concluded that the extract in the concentration of 3\%, 4\% and 5\% applied in coffee, presented positive allelopathy in relation to the parameters of the root system.
\end{abstract}

Keywords: Inhibitors, Cafeiculture, Weeds

\section{INTRODUCTION}

Coffee cultivation is considered as one of the main activities of the agricultural sector, largely responsible for the economic development of Brazil. According to surveys carried out in recent years, Brazil is the largest coffee producer in the world. Minas Gerais also occupies a prominent place in the cultivation of coffee, being considered the Brazilian state that performs most of the country's coffee production, responsible for more than half of the Brazilian production (Fapemig, 2018).

Studies point out the unquestionable importance of coffee to the world economy, since coffee is the second most valuable primary product on the international market, behind oil only (Santos et al., 2014) and as highlighted by Fernandes (2011), in Brazil, coffee farming is highlighted in agribusiness, being the country that produced the most coffee in the last 150 years. 
International Journal of Agriculture and Environmental Research

ISSN: 2455-6939

Volume: 06, Issue: 06 "November-December 2020"

According to Tokura and Nóbrega (2006), the term allelopathy refers to the union of the words allélon and pathos, which mean, respectively, mutual and prejudice. For the authors, allelopathy is the ability of higher or lower plants to produce chemical substances that, when released into the environment of others, influence their development in a favorable or unfavorable way.

Allelopathy has as its main objective to contribute to increased productivity, which according to Carvalho et al. (2016) this effect can inhibit or stimulate a plant on other species, resulting from the release of chemical substances in the environment, also contributing to the reduction of the weed population.

The tiririca (Cyperus rotundus L.) is defined by Silveira et al. (2010) as a weed species that is difficult to manage, causing the reduction of the stand and the yield in commercial plantations of the most varied cultures. Due to its aggressiveness, reproduction capacity, high dispersion and rusticity, its control is difficult and costly.

In the view of Spósito et al. (2016), the genus Cyperus is part of the Cyperaceae family, where it is represented by herbaceous that grow, mostly, in humid places. This genus has 550 species that are widely distributed geographically, mostly in tropical and subtropical regions. For the authors, even though they are considered invasive plants and have a great negative impact on agricultural production, studies have been pointing out that tiririca has great biological potential that can attribute important economic value to these species.

The Cyperus rotundus L., better known astiririca, is well known in agriculture for having allelopathic effects. In addition, tiririca has substances that benefit the development of coffee seedlings, a considerable example is its high level of Indole Butyric Acid, a specific phytoregulatory acid for the formation of plant roots (Andrade et al.,2009).

Studies have been developed in order to reduce the use of herbicides through allelopathy as the management and control of invasive plants, through crop rotation, adequate seeding systems between species and off-season, in addition to agro-ecological systems (Kato, 2003).

The use of allelopathy between plants in the control of tiriricas over Arabica coffee seedlings is characterized by the deposition of mulches or plant residues. This mulch provides protection for the seedling, enriches the soil with organic matter and some nutrients for the plant (Santos et al., 2014).

According to Santos et al. (2014) the use of cover has become a common and empirical practice among coffee growers as an alternative for soil management and fertilization, and its consequent interference on weeds. 
International Journal of Agriculture and Environmental Research

ISSN: 2455-6939

Volume: 06, Issue: 06 "November-December 2020"

Thus, the study aimed to evaluate the effect of different concentrations of tiririca extract (Cyperus rotundus L.) on the development of arabica coffee seedlings.

\section{MATERIAL AND METHODS}

The survey was carried out from March to May 2020, in the municipality of Carvalhópolis-MG, located at coordinates with Latitude $21^{\circ} 46^{\prime} 15^{\prime \prime}$ South, Longitude $45^{\circ} 49^{\prime} 44^{\prime \prime}$ West, with an altitude of 882 meters and a predominant climate in the area it is temperate (Climate-data.org, 2020).

The soil used as a component of the substrate of the pots where it was implanted in Arabica coffee seedlings (Coffea arabica L.) was removed from a pasture, distant from coffee crops, later sieved, being characterized as red-yellow latosol and added in plastic bags of $32 \mathrm{dm} 3$. The coffee seedlings of the cultivar catuai Vermelho IAC 144 were planted on 03/17/2020 and the tiririca plants (Cyperus rotundus L.) were collected in a soccer field, known as Estádio Felipão, located in the city of Carvalhópolis-MG.

The tiririca plants were washed with water and ground pure using a blender. Then this mass of tiririca (Cyperus rotundus L.) which was weighed to make the appropriate concentrations.

The treatments used were as follows:

- Treatment 1 / control, which has not been applied;

- Treatment 2 tiririca extract at $1 \%$;

- Treatment 3 tiririca extract at $2 \%$;

- Treatment 4 tiririca extract at $3 \%$

- Treatment 5 tiririca extract at 4\%;

- Treatment 6 tiririca extract at $5 \%$.

The treatments were applied with the help of a watering can and the irrigation was done every two days, with a volume of $700 \mathrm{~mL}$ of water per treatment.

In the top dressing fertilization, 70 grams of super simple phosphate $\left(18 \% \mathrm{P}_{2} \mathrm{O}_{5}\right)$ were placed in all treatments.

The treatments were installed in 4 replications, totaling 24 experimental plots, in a randomized block design (DBC).

On 03/17/2020 concentrations of titirica extract were applied to the seedlings and on 05/30/2020, (74 days after application) the height of the coffee plant $(\mathrm{cm})$, root height $(\mathrm{cm})$ and aerial part $(\mathrm{cm})$, dry and fresh weight of aerial part, root part $(\mathrm{g})$ and total weight $(\mathrm{g})$. The surveyed results 
were subjected to analysis of variance and the comparison of the averages made by the ScottKnott test, at 5\% probability, both using the SISVAR ${ }^{\circledR}$ software (Ferreira, 2014).

\section{RESULTS AND DISCUSSION}

After 74 days of the application of tiririca extract, the seedlings were evaluated, and the results (Table 1) referring to the evaluation of different concentrations of tiririca extract (Cyperus rotundus L.) on Coffea arabica seedlings, we can observe among the treatments the characteristics Aerial part Length (AL), Root Length (RL), Aerial Fresh Mass Weight (AFMW), Root Fresh Mass Weight (RFMW), Air Dry Weight (ADW), Root Dry Weight (PSR) and total dry weight (TDW).

Table 1: Average results of aerial part length (AL), root length (RL), aerial fresh mass weight (AFMW), radicular fresh mass weight (RFMW), aerial dry weight (ADW), root dry weight (RDW) and total dry weight of coffee seedlings submitted to tiririca extract (TDW).

\begin{tabular}{cccccccc}
\hline \multirow{2}{*}{ Treatments } & $\begin{array}{c}\text { AL } \\
(\mathbf{c m})\end{array}$ & $\begin{array}{c}\text { RL } \\
(\mathbf{c m})\end{array}$ & $\begin{array}{c}\text { AFMW } \\
(\mathbf{g})\end{array}$ & $\begin{array}{c}\text { RFMW } \\
(\mathbf{g})\end{array}$ & $\begin{array}{c}\text { ADW } \\
(\mathbf{g})\end{array}$ & $\begin{array}{c}\text { RDW } \\
(\mathbf{g})\end{array}$ & $\begin{array}{c}\text { TDW } \\
(\mathbf{g})\end{array}$ \\
\hline $\mathbf{0 \%}$ Control & $35,5 \mathrm{~A}$ & $21,8 \mathrm{C}$ & $8,2 \mathrm{~A}$ & $4,8 \mathrm{~B}$ & $3,5 \mathrm{~A}$ & $2,5 \mathrm{~B}$ & $6,0 \mathrm{~A}$ \\
$\mathbf{1 \%}$ & $33,5 \mathrm{~A}$ & $20,2 \mathrm{D}$ & $5,5 \mathrm{~B}$ & $5,0 \mathrm{~B}$ & $2,2 \mathrm{~B}$ & $2,0 \mathrm{~B}$ & $4,2 \mathrm{C}$ \\
$\mathbf{2 \%}$ & $31,8 \mathrm{~B}$ & $22,2 \mathrm{~B}$ & $5,5 \mathrm{~B}$ & $5,0 \mathrm{~B}$ & $2,2 \mathrm{~B}$ & $2,0 \mathrm{~B}$ & $4,2 \mathrm{C}$ \\
$\mathbf{3 \%}$ & $35,0 \mathrm{~A}$ & $23,0 \mathrm{~B}$ & $5,5 \mathrm{~B}$ & $6,2 \mathrm{~A}$ & $2,0 \mathrm{C}$ & $3,2 \mathrm{~A}$ & $5,2 \mathrm{~B}$ \\
$\mathbf{4 \%}$ & $32,5 \mathrm{~A}$ & $24,8 \mathrm{~A}$ & $4,0 \mathrm{C}$ & $5,5 \mathrm{~B}$ & $1,8 \mathrm{C}$ & $2,8 \mathrm{~B}$ & $4,6 \mathrm{C}$ \\
$\mathbf{5 \%}$ & $31,5 \mathrm{~B}$ & $25,2 \mathrm{~A}$ & $5,2 \mathrm{~B}$ & $6,5 \mathrm{~A}$ & $2,5 \mathrm{~B}$ & $3,0 \mathrm{~A}$ & $5,5 \mathrm{~B}$ \\
\hline
\end{tabular}

*Different letters in the column, differ statistically by the Scoot-Knott test at 5\% probability

Regarding the length of the aerial part of the coffee seedlings, the control, $1 \%, 3 \%$ and $4 \%$, were the same and statistically superior to the others.

With regard to Root Length (RL), the treatments where the concentrations of sedge extract in the order of $4 \%$ and $5 \%$ were used were equal and higher with higher RL, compared to the control, this is due to the allopathic effect positive of the sedge. According to Silva et al. (2011), the aqueous extract of tiririca (Cyperus rotundus L.), considered the main weed, also has a positive allelopathic effect, as it induces the root growth of coffee cuttings. 
International Journal of Agriculture and Environmental Research

ISSN: 2455-6939

Volume: 06, Issue: 06 "November-December 2020"

Observing the aerial dry weight (ADW), the concentrations 3\% and 4\%, presented inferior results when compared with the control. One of the justifications adopted to explain this result is the negative role that tiririca can bring to commercial culture. In their studies, Melhoranca et al. (2008) reported that the allelopathic potential of tiririca caused a significant decrease in the size of the hypocotyl, an expression that is largely due to the fact that the allelopathic profile of the weed plant on lettuce seeds.

For the weight of fresh air mass (AFMW), the use of the 4\% extract showed a statistically inferior result in relation to the control and other treatments. El-Rokiek et al. (2010) affirms that the species produces allelopathic substances, such as phenolic allelochemicals, hydroxybenzoic acid, caffeine, ferulic, chlorogenic and vanelic substances that can affect the germination and development of other species.

When using 3\%, 4\% and 5\% tiririca extract concentrations, for the weight of fresh root mass, the treatments presented the highest RFMW compared to the control. According to research conducted by Arruda (2009) and Bedin et al. (2006) these prove the effectiveness of using plant extracts such as tiririca, lemongrass, bilberry, eucalyptus, among other species, as natural inhibitors of weed growth and germination or as stimulants for the development of the root system of some specific crops.

Regarding root dry weight (RDW), when compared to the control and other concentrations, the $3 \%$ and 5\% concentrations that obtained the worst statistical results are due to the positive effect of the tiririca extract, says the authors Burg and Mayer (2006) the aqueous extract of this plant contains substances, probably plant hormones, that contribute to the promotion and induction of roots.

Regarding the total dry weight (TDW) of coffee seedlings submitted to tiririca extract, the concentrations $1 \%, 2 \%$ and $4 \%$ when analyzed with the control obtained less weight.

\section{CONCLUSION}

It is concluded that the extract in the concentration of 3\%, 4\% and 5\% applied in coffee, presented positive allelopathy in relation to the parameters of the root system.

\section{REFERENCES}

Andrade, H.M., Bittencourt, A.H.C, Silvane, V. 2009. Potencial alelopático de Cyperus rotundus L. sobre espécies cultivadas. Ciência e Agrotecnologia. Lavras, 33, Edição especial, 1984-1990.

Arruda, L.A.M. 2009.Atividade hormonal do extrato de tiririca na rizogênese de estacas de sapoti. In: IX Jornada de Ensino, Pesquisa e Extensão da UFRPEJEPEX. 
International Journal of Agriculture and Environmental Research

ISSN: 2455-6939

Volume: 06, Issue: 06 "November-December 2020"

Bedin, C. et al. 2006. Efeito alelopático de extrato de Eucalyptus citriodora na germinação de sementes de tomate (Lycopersicumesculentum M.). Revista Científica Elet. Agron., $5(10), 1-7$.

Burg, I.C., Mayer, P.H. 2006 Alternativas ecológicas para prevenção e controle de pragas e doenças. 30 ed. Francisco Beltrão: Grafit Gráfica e Editora Ltda.

Carvalho, P. et al. 2016. Alelopatia de resíduos de plantas de cobertura no controle de braquiária cv. Marandu. Revista Brasileira de Biociências, Porto Alegre, 14(2), 60-69.

Climate-data.org. Clima: Nova Crixás, 2020. Disponível em: <http:// pt.climatedata.org/location/43194/>. Acesso em: 20 out. 2020.

El-Rokiek, K., El-Din, S., Sharara, F. 2010. Comportamento alelopático de Cyperus rotundus L. emambos Chorchorus olitorius (erva daninha de folhas largas) e Echinochloa crus-galli (erva daninha) associada à soja. Journal of Plant Protection Research, 2010.

Fapemig. 2018. A produção de café em Minas Gerais: desafios para a industrialização. Fundação João Pinheiro, Diretoria de Estatística e Informações. - Belo Horizonte: FJP.

Fernandes, N. 2011. A Mecanização como saída para escassez de mão-de-obra e aumento da competitividade dos cafés brasileiros. Revista do Café, Rio de Janeiro, 837, 40-41.

Ferreira, D.F. 2014. Sisvar: um guia dos seus procedimentos de comparações múltiplas Bootstrap. Ciência e Agrotecnologia, 38(2), 109-112. Disponível em: <https://doi.org/10.1590/S1413-70542014000200001>.Acesso em: 20 set. 2020.

Kato, N.H. 2003. Avaliação do potencial alelopático do pó do caule de erva-cidreira. Scientia Horticultutae, Amsterdam, 97.

Melhoranca, A.L.F. 2008. Produtividade de alface cv Lucy Brown influenciada por períodos de convivência com plantas infestantes e potencial alelopático da tiririca. BioscienceJournal. 24(3), 19-23.

Santos, J.C.F. et al. 2014. Manejoagroecológico de plantas daninhas da cultura do café. Porto Velho, RO: Embrapa Rondônia, 2014.

Silveira, H.R.O. et al. 2010. Alelopatia e homeopatia no manejo da tiririca (Cyperusrotundus). Planta Daninha, 28(3), 499-506. Disponível em: <https://doi.org/10.1590/S010083582010000300006 >. Acesso em> 10 set. 2020.

Spósito, R. C. A., Virgens, R. S., Pungartnik, C. 2016. Investigação prospectiva sobre a utilização do gênero cyperus na geração de tecnológicas. Cadernos de Prospecção, 
International Journal of Agriculture and Environmental Research

ISSN: 2455-6939

Volume: 06, Issue: 06 "November-December 2020"

Salvador, $\quad 9(1), \quad 38-44 . \quad$ Disponível em: <https://portalseer.ufba.br/index.php/nit/article/view/11581>. Acesso em: 24 out. 2020.

Tokura, L. K., Nóbrega, L.H.P. 2006. Alelopatia de cultivos de cobertura vegetal sobre plantas infestantes. Rede de Revistas Científicas da América Latina, 28(3), 379-384 Disponível em: <https://www.redalyc.org/pdf/3030/303026570006.pdf>. Acesso em: 29 out. 2020.

Silva, E. D. 2011. Crescimento de mudas de cafeeiro em extrato de tiririca. VII Simpósio de Pesquisa dos Cafés do Brasil 22 a 25 de Agosto de 2011. Disponível em: <http://www.sapc.embrapa.br/arquivos/consorcio/spcb_anais/simposio7/305.pdf>. Acesso em 10 out. 2020. 